\title{
Comprehensive evaluation of fluroxypyr herbicide on physiological parameters of spring hybrid millet
}

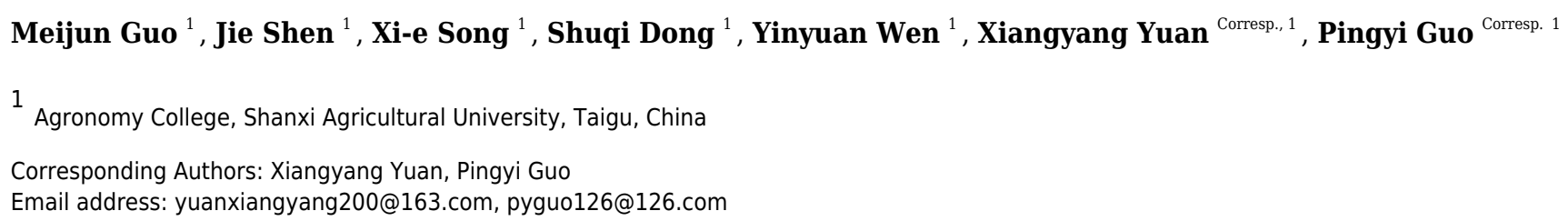

Foxtail millet (Setaria italic L.) is an important food and fodder crop that is cultivated worldwide. Quantifying the effects of herbicides on foxtail millet is critical for safe herbicide application. In this study, we analyzed the effects of different fluroxypyr dosages on the growth parameters and physiological parametric of foxtail millet, that is, peroxidation characteristics, photosynthetic characteristics, and endogenous hormone production, by using multivariate statistical analysis. Indicators were screened via Fisher discriminant analysis, and the growth parameters, peroxidation characteristics, photosynthesis characteristics and endogenous hormones of foxtail millet at different fluroxypyr dosages were comprehensive evaluated by principal component analysis. On the basis of the results of principal component analysis, the cumulative contribution rate of the first two principal component factors was $93.72 \%$. The first principal component, which explained $59.23 \%$ of total variance, was selected to represent the photosynthetic characteristics and endogenous hormones of foxtail millet. The second principal component, which explained $34.49 \%$ of total variance, represented the growth parameters of foxtail millet. According to the principal component analysis, the indexes were simplified into comprehensive index $Z$, and the mathematical model of comprehensive index $Z$ was set as $F=0.592 Z_{1}+0.345 Z_{2}$. The results showed that the comprehensive evaluation score of fluroxypyr at moderate concentrations was higher than at high concentrations.

Consequently, $1 \mathrm{~L}$ (active ingredient, ai) ha ${ }^{-1}$ fluroxypyr exerted minimal effects on growth parameters, oxidase activity, photosynthetic activity, and endogenous hormones, and had highest value of comprehensive evaluation, which had efficient and safe benefits in foxtail millet field. 
1 Comprehensive evaluation of fluroxypyr herbicide on physiological parameters of spring hybrid millet

3 Meijun $\mathrm{Guo}^{1+}$, Jie Shen ${ }^{1}$, Xi-e Song ${ }^{1}$, Shuqi Dong ${ }^{1}$, Yinyuan Wen ${ }^{1}$, Xiangyang Yuan ${ }^{1 *}$, and Pingyi Guo ${ }^{1 *}$

$4{ }^{1}$ Agronomy College, Shanxi Agricultural University, Taigu, China

5 Author for correspondence: Pingyi Guo (E-mail: pyguo126@126.com)

6 Xiangyang Yuan (E-mail:yuanxiangyang200@163.com)

\section{ABSTRACT}

Foxtail millet (Setaria italic L.) is an important food and fodder crop that is cultivated worldwide.

Quantifying the effects of herbicides on foxtail millet is critical for safe herbicide application. In this study, we

analyzed the effects of different fluroxypyr dosages on the growth parameters and physiological parametric of

foxtail millet, that is, peroxidation characteristics, photosynthetic characteristics, and endogenous hormone

production, by using multivariate statistical analysis. Indicators were screened via Fisher discriminant analysis,

and the growth parameters, peroxidation characteristics, photosynthesis characteristics and endogenous

hormones of foxtail millet at different fluroxypyr dosages were comprehensive evaluated by principal

component analysis. On the basis of the results of principal component analysis, the cumulative contribution

rate of the first two principal component factors was $93.72 \%$. The first principal component, which explained

$59.23 \%$ of total variance, was selected to represent the photosynthetic characteristics and endogenous

hormones of foxtail millet. The second principal component, which explained $34.49 \%$ of total variance,

represented the growth parameters of foxtail millet. According to the principal component analysis, the indexes

$\mathrm{F}=0.592 \mathrm{Z}_{1}+0.345 \mathrm{Z}_{2}$. The results showed that the comprehensive evaluation score of fluroxypyr at moderate 
22 concentrations was higher than at high concentrations. Consequently, 1 L (active ingredient, ai) ha ${ }^{-1}$

23 fluroxypyr exerted minimal effects on growth parameters, oxidase activity, photosynthetic activity, and endogenous hormones, and had highest value of comprehensive evaluation, which had efficient and safe benefits in foxtail millet field.

\section{INTRODUCTION}

Foxtail millet (Setaria italica L.) is a valuable economic crop because it is rich in protein and crude fat and used as a staple food worldwide. This plant has seven essential amino acids, and its contents are higher than those found in other crops. In particular, methionine and tryptophan, which are important in preventing atherosclerosis and softening the blood vessel, are abundant in this plant. However, weed infestation has severely limited foxtail millet production in China (Guo et al., 2018). Weeds are the most important biotic factor affecting agricultural production; they are responsible for over $55.56 \%$ of total foxtail millet yield losses (Zhou et al., 2012). For weed control, herbicide application is considered the most cost-efficient and effective method (Rubin, 1996). Rational application of herbicides, such as monosulfuron, monosulfuron mix propazine, 2,4-D, and prometryn, can effectively control weeds in foxtail millet fields; however, these herbicides readily cause phytotoxicity reaction (Tian \& Wang, 2010). Thus, finding suitable herbicides for use in foxtail millet field is a considerable challenge in weed control. fallow cropland fields, to control annual or perennial weeds (Hellou et al., 2009). These herbicides cause auxin overdose or excessive endogenous auxin concentrations, thereby resulting in an imbalance of auxin homeostasis and interaction with other hormones in tissues, which ultimately cause the succeeding series of 
43

44

45

46

47

48

49

50

51

52

53

54

55

56

57

58

59

60

61

62

63

demonstrated that the label fluroxypyr dose can be used in maize (Zea mays) and winter wheat (Triticum

aestivum) fields, and has desirable control effects on broadleaf weeds. Considering the significant differences

in the sensitivity of crop varieties to fluroxypyr, it is necessary to indicate whether fluroxypyr is safe for use on

foxtail millet.

Foxtail millet tolerance toward herbicides depends on either the alteration of the target site (TS) or non-

target site (NTS) mechanisms. TS resistance mechanism is manifested by structural changes due to point

mutations in herbicide-binding proteins, such as the D1 protein in the photosystem II (PSII) complex (Thiel \&

Varrelmann, 2014), acetolactate synthase (Tranel, Wright \& Heap, 2014), acetyl-CoA carboxylase (Kaundun,

2014), or 5-enolpyruvylshikimate-3-phosphate synthase (EPSPS) (Sammons \& Gaines, 2014). TS resistance

mechanism is occasionally the result of an increased number of copies of the target gene, such as EPSPS

(Gaines et al., 2010; Vila-Aiub et al., 2014). The NTS mechanism involves herbicide detoxification by

glutathione S-transferase or cytochrome P450 monooxygenase, reduced absorption or translocation in the plant

and sequestration into vacuoles (Matzrafi et al., 2014). In contrast to TS, NTS resistance mechanisms can

occasionally be more widespread and exhibit resistance to many herbicides. However, information regarding

the physiological mechanism of Zhangzagu hybrid millet after the application of fluroxypyr is limited. Thus,

the NTS resistance mechanisms to fluroxypyr in spring hybrid millet should be understood.

The hybrid foxtail millet 'Zhangzagu' is popular, especially Zhangza 5, with a large production area in China due to its high yield, drought resistance, and nutritional value (Dong et al., 2014). Thus, we used

Zhangza 5 as the model species for the present study, especially for the study of the physiological mechanism

due to tolerance against fluroxypyr. Herein, the objective of this study are as follows: (1) to comprehensively

investigate the influence of different dosages of fluroxypyr on the growth and physiological mechanism of

Peer] reviewing PDF | (2019:02:34816:3:0:NEW 23 Aug 2019) 
spring hybrid millet; (2) to further understand the NTS resistance mechanisms to fluroxypyr-induced oxidative stresses; (3) to compare and analyze the main factors contributing to the effect of fluroxypyr on spring hybrid millet growth. Thus, we provided convincing evidence for the correlations of NTS resistance to fluroxypyr exposure, and aimed at obtaining the optimal fluroxypyr application dose for spring hybrid millet.

\section{MATERIALS AND METHODS}

\section{Plant and experimental design}

Fluroxypyr (20\%, emulsifiable concentrate) was provided by Dow AgroScience Co. (Jiangsu, China). Foxtail millet (Setaria italica L. cv. Zhangza 5) was supplied by the Zhangjiakou Academy of Agricultural Sciences of Hebei Province, China. The seeds were uniformly sown in a plastic pot (130 $\mathrm{mm}$ diameter) containing a mixture of sand and soil (1:2, v:v). Calcareous cinnamon soil, with a $\mathrm{pH}$ of $7.85,24.49 \mathrm{~g} \mathrm{~kg}^{-1}$ organic matter, $51.92 \mathrm{mg} \mathrm{kg}^{-1}$ total nitrogen, $24.13 \mathrm{mg} \mathrm{kg}^{-1}$ available phosphorus, and $183.6 \mathrm{mg} \mathrm{kg}^{-1} \mathrm{rapidly}^{-}$ available potassium was used in this work. At the three-leaf stage, the foxtail millet seedlings were thinned and maintained at 10 uniform plants per pot.

The experiment was conducted as a randomized complete block design with three replications. After growing to the five-leaf stage, foxtail millet seedlings were treated with $0,0.5,1,2$, and $4 \mathrm{~L}$ ai ha ${ }^{-1}$ fluroxypyr by using a laboratory pot-sprayer equipped with a nozzle and previously calibrated to deliver $450 \mathrm{~L} \mathrm{ha}^{-1}$. The manufacturer recommended an effective dose of $1 \mathrm{~L}$ ai ha- ${ }^{-1}$ for field application. After herbicide treatment for 5 and 10 days, the physiological indices of all foxtail millet seedlings were analyzed.

\section{Measurement of growth parameters}

The plant height, length and width of leaves were measured with a ruler. Leaf area was calculated using the following equation: leaf area $=0.75 \times$ leaf length $\times$ leaf width. Leaf width was considered the widest part of 
85

86

87

88

89

90

91

92

93

94

95

96

97

98

99

100

101

102

103

104

105

the penultimate leaf.

\section{Determination of superoxide generation rate and $\mathrm{H}_{2} \mathrm{O}_{2}$ content}

Fresh foxtail millet leaves $(0.1 \mathrm{~g})$ were homogenized with $2 \mathrm{~mL}$ of $65 \mathrm{mmol} \mathrm{L}^{-1}$ sodium phosphate buffer (pH 7.8) and centrifuged at 10,000 rpm for $10 \mathrm{~min}$. The supernatant $(1 \mathrm{~mL})$ was mixed with $1 \mathrm{~mL}$ of $65 \mathrm{mmol}$ $\mathrm{L}^{-1}$ sodium phosphate buffer ( $\mathrm{pH} 7.8$ ) and $0.2 \mathrm{~mL}$ of $10 \mathrm{mmol} \mathrm{L}^{-1}$ hydroxyl ammonium chloride. The resulting supernatant was incubated $25^{\circ} \mathrm{C}$ for $20 \mathrm{~min}$, and the above reaction mixture $(1 \mathrm{~mL})$ was mixed with $1 \mathrm{ml}$ of 4 aminobenzene sulfonic acid $\left(17 \mathrm{mmol} \mathrm{L}^{-1}\right)$ and $1 \mathrm{~mL}$ of $\alpha$-naphthylamine $\left(7 \mathrm{mmol} \mathrm{L}^{-1}\right)$, then incubated at 30 ${ }^{\circ} \mathrm{C}$ for $30 \mathrm{~min}$. The absorbance at $530 \mathrm{~nm}$ was measured with a $756 C-U V-V I S$ spectrophotometer (Shanghai Spectrum Instruments Co. Ltd) (Elstner \& Heupel, 1976).

Fresh foxtail millet leaves $(0.1 \mathrm{~g})$ were homogenized with $5 \mathrm{~mL}$ of chilled acetone in an ice bath and centrifuged at $4,000 \mathrm{rpm}$ for $15 \mathrm{~min}$. The supernatant $(1 \mathrm{~mL})$ was mixed with $0.1 \mathrm{~mL}$ of $20 \% \mathrm{TiCl}_{4}$ concentrated hydrochloric acid and $0.2 \mathrm{~mL}$ of concentrated ammonium hydroxide. The reaction mixture was centrifuged at 10,000 rpm for $10 \mathrm{~min}$ and the precipitate was dissolved in $3 \mathrm{~mL} \mathrm{H}_{2} \mathrm{SO}_{4}\left(1 \mathrm{~mol} \mathrm{~L}^{-1}\right)$. The absorbance of the supernatant at $410 \mathrm{~nm}$ was monitored with a $756 C-U V-V I S$ spectrophotometer (Zhang et al., 2012).

\section{Determination of antioxidant enzyme activities}

Fresh foxtail millet leaves $(0.1 \mathrm{~g})$ were homogenized with $2 \mathrm{~mL}$ of sodium phosphate buffer $(\mathrm{pH} 7.0$, containing $0.1 \mathrm{mmol} \mathrm{L}^{-1}$ EDTA and 1\% PVP (w/v)) in an ice bath. The homogenate was centrifuged at 10,000 rpm for $15 \mathrm{~min}$ at $4^{\circ} \mathrm{C}$. The supernatant was extracted and used to measure the activities of superoxide (SOD), peroxidase (POD), catalase (CAT), and ascorbate peroxidase (APX). The samples were measured with a 756C$U V$-VIS spectrophotometer. 
SOD activity was analyzed by using the nitro blue tetrazolium (NBT) method. The reaction mixture $(5 \mathrm{~mL})$ consisted of phosphate buffer (50 mmol L $\left.{ }^{-1}, \mathrm{pH} 7.8\right)$, L-methionine $\left(13 \mathrm{mmol} \mathrm{L}^{-1}\right)$, NBT $\left(0.075 \mathrm{mmol} \mathrm{L}^{-1}\right)$, EDTA $\left(0.1 \mathrm{mmol} \mathrm{L}^{-1}\right)$, riboflavin $\left(0.002 \mathrm{mmol} \mathrm{L}^{-1}\right)$, and $20 \mu \mathrm{L}$ of enzyme extract. The reaction mixture was then illuminated under $4000 \mathrm{~lx}$ for $15 \mathrm{~min}$ at $25^{\circ} \mathrm{C}$. One unit of activity corresponds to the amount of protein required to inhibit $50 \%$ of the initial reduction of NBT under light conditions. The absorbance at $560 \mathrm{~nm}$ was measured, and a non-irradiated complete reaction mixture served as the control. For POD activity determination, $20 \mu \mathrm{L}$ of enzyme extract was added into $3 \mathrm{~mL}$ of reaction liquid containing $3 \mathrm{~mL}$ of sodium phosphate buffer (100 mmol L $\left.{ }^{-1}, \mathrm{pH} 6.0\right), 19 \mu \mathrm{L}$ of guaiacol, and $28 \mu \mathrm{L}$ of $30 \% \mathrm{H}_{2} \mathrm{O}_{2}$. POD activity was measured by the changes in the absorbance of the reaction solution at $470 \mathrm{~nm}$ for $3 \mathrm{~min}$. For CAT activity determination, the reaction liquid consisted of $2.7 \mathrm{~mL}$ of Tris- $\mathrm{HCl}\left(50 \mathrm{mmol} \mathrm{L}^{-1}, \mathrm{pH} 7.0\right), 50 \mu \mathrm{L}$ of $\mathrm{H}_{2} \mathrm{O}_{2}(200$ $\mathrm{mmol} \mathrm{L} \mathrm{L}^{-1}$ ), and $20 \mu \mathrm{L}$ of enzyme extract. Enzyme activity was continuously determined at $240 \mathrm{~nm}$ for $3 \mathrm{~min}$ following $\mathrm{H}_{2} \mathrm{O}_{2}$ decomposition. In accordance with the method of APX activity determination by Nakano \& Asada (1981), the reaction mixture consisted of $3 \mathrm{~mL}$ sodium phosphate buffer (50 mmol L-1, $\mathrm{pH} 7.0), 0.4 \mathrm{~mL}$ of EDTA $\left(0.3 \mathrm{mmol} \mathrm{L}{ }^{-1}\right), 1 \mathrm{~mL}$ of ascorbate $\left(0.9 \mathrm{mmol} \mathrm{L}^{-1}\right)$, and $1 \mathrm{~mL}$ of enzyme extract. The reaction mixture was then incubated for $5 \mathrm{~min}$ at $25{ }^{\circ} \mathrm{C}$. The above reaction mixture was mixed with $0.5 \mathrm{~mL}$ of $\mathrm{H}_{2} \mathrm{O}_{2}$ (0.25 mmol L-1), and $\mathrm{H}_{2} \mathrm{O}_{2}$ decomposition was measured by the decline in absorbance at $290 \mathrm{~nm}$ for 1 min.

Glutathione reductase (GR) activity was analyzed according to Halliwell \& Foyer (1978). Fresh foxtail millet leaves $(0.1 \mathrm{~g})$ were ground in an ice bath with $2 \mathrm{~mL}$ of Tris- $\mathrm{HCl}(\mathrm{pH} 7.5$, containing $1 \% \mathrm{PVP}$ and 0.1 mmol L ${ }^{-1}$ EDTA), and centrifuged at $10,000 \mathrm{rpm}$ for $15 \mathrm{~min}$ at $4^{\circ} \mathrm{C}$. The enzyme extract $(150 \mu \mathrm{L})$ was added into $3 \mathrm{~mL}$ of reaction liquid including Tris- $\mathrm{HCl}(\mathrm{pH} 7.5), \mathrm{MgCl}_{2}\left(3 \mathrm{mmol} \mathrm{L}^{-1}\right)$, GSSG $\left(0.5 \mathrm{mmol} \mathrm{L}^{-1}\right)$, and NADPH $\left(0.15 \mathrm{mmol} \mathrm{L}^{-1}\right)$. Enzyme activity was calculated by the change in absorbance at $340 \mathrm{~nm}$ for $3 \mathrm{~min}$. 
127

128

129

130

131

132

133

134

135

136

137

138

139

140

141

142

143

144

145

146

147

\section{Determination of photosynthetic gas exchange and chlorophyll}

Photosynthetic rate $\left(P_{N}\right)$, transpiration rate $(E)$, and stomatal conductance $\left(G_{s}\right)$ were measured by CI-340 portable photosynthesis system (CID Bio-Science, Inc., USA) from 9:30 to 10:30 am. The photosynthetically active radiation (PAR) at the leaf surface was approximately $11000 \pm 50 \mu \mathrm{mol} / \mathrm{m}^{2} / \mathrm{s}$, the temperature of the leaf chamber was $30 \pm 2{ }^{\circ} \mathrm{C}$, and the ambient $\mathrm{CO}_{2}$ concentration was $380 \pm 50 \mu \mathrm{mol} / \mathrm{mol}$.

To measure photosynthetic pigments, fresh leaves $(0.1 \mathrm{~g})$ were soaked in $10 \mathrm{~mL}$ of ethanol $(96 \%$, v/v) and stored in the dark for $24 \mathrm{~h}$. The absorbance of the supernatants was measured at 649 and $665 \mathrm{~nm}$ with a $756 C$ UV-VIS spectrophotometer (Lichtenthaler, 1987).

\section{Measurement of chlorophyll fluorescence and $\mathbf{P}_{700}$ parameters}

The chlorophyll fluorescence and $\mathrm{P}_{700}$ parameters were simultaneously detected using a luminoscope (Dual PAM-100, WALZ, Germany) (Pfündel, Klughammer \& Schreiber, 2008). After dark adaptation for 30 minutes, the kinetics of chlorophyll fluorescence induction and P700 oxidation were simultaneously detected according to the "Fluo $+\mathrm{P}_{700}$ " analysis mode.

First, the minimal fluorescence $\left(\mathrm{F}_{0}\right)$ was detected under weak light $\left(7 \mu \mathrm{mol} / \mathrm{m}^{2} / \mathrm{s}\right)$. Subsequently, the maximum fluorescence $\left(\mathrm{F}_{\mathrm{m}}\right)$ was determined by the saturation pulse $\left(4000 \mu \mathrm{mol} / \mathrm{m}^{2} / \mathrm{s}, 800 \mathrm{~ms}\right)$ method. The slow induction curve was calculated as follows: $F_{v} / F_{m}=\left(F_{m}-F_{0}\right) / F_{m}, E_{R} R_{I I}=P A R \times 0.84 \times 0.5 \times Y_{I I}, Y_{I I}=$ $\left(F_{\mathrm{m}}{ }^{\prime}-\mathrm{F}\right) / \mathrm{F}_{\mathrm{m}}{ }^{\prime}, \mathrm{Y}_{\mathrm{NO}}=1 /\left(\mathrm{NPQ}+1+\mathrm{qL}\left(\mathrm{F}_{\mathrm{m}} / \mathrm{F}_{0}-1\right)\right), \mathrm{Y}_{\mathrm{NPQ}}=1-\mathrm{Y}_{\mathrm{II}}-\mathrm{Y}_{\mathrm{NO}}$, where $\mathrm{F}_{\mathrm{v}} / \mathrm{F}_{\mathrm{m}}$ and $\mathrm{Y}_{\mathrm{II}}$ are the maximum PSII quantum yield and effective PSII quantum yield, respectively, and $\mathrm{Y}_{\mathrm{NPQ}}$ and $\mathrm{Y}_{\mathrm{NO}}$ are the regulated energy dissipation and non-regulated energy dissipation, respectively.

$\mathrm{P}_{700}$ oxidation was monitored by the changes in the transmittance signals at $875 \mathrm{~nm}$ and $830 \mathrm{~nm}$ (Klughammer \& Schreiber, 2008). The maximal $\mathrm{P}_{700}\left(\mathrm{P}_{\mathrm{m}}\right)$ was denoted by the maximal $\mathrm{P}_{700}$ signal reduction to 
148 full oxidation. $\mathrm{Y}_{\mathrm{NA}}$, the nonphotochemical quantum yield of PSI, is a measure of the acceptor-side limitation

149 and calculated according to the formula $\mathrm{Y}_{\mathrm{NA}}=\left(\mathrm{P}_{\mathrm{m}}{ }^{\prime}-\mathrm{P}_{\mathrm{m}}\right) / \mathrm{P}_{\mathrm{m}}$. $\mathrm{Y}_{\mathrm{I}}$, the photochemical quantum yield of PSI,

150 was calculated according to the formula $\mathrm{Y}_{\mathrm{I}}=\left(\mathrm{P}_{\mathrm{m}}{ }^{\prime}-\mathrm{P}\right) / \mathrm{P}_{\mathrm{m}}$. $\mathrm{Y}_{\mathrm{ND}}$, the nonphotochemical quantum yield of PSI, is

151 a measure of the donor side limitation and calculated as $\mathrm{Y}_{\mathrm{ND}}=\left(\mathrm{P}-\mathrm{P}_{0}\right) / \mathrm{P}_{\mathrm{m}}$. The sum of these three quantum

152 yields is one, i.e.: $\mathrm{Y}_{\mathrm{I}}+\mathrm{Y}_{\mathrm{ND}}+\mathrm{Y}_{\mathrm{NA}}=1$. The electron transfer efficiency of PSI, ETR $\mathrm{I}_{\mathrm{I}}$ was assessed by the Dual

153 PAM software.

154 Measurement of endogenous hormones

Fresh foxtail millet leaves $(0.5 \mathrm{~g})$ were homogenized with $4 \mathrm{~mL}$ of $80 \%$ methanol (1 mmol/L 2, 6-di-tert-

butyl-4-methylphenol) in an ice bath. The homogenate mixture was refrigerated at $4{ }^{\circ} \mathrm{C}$ for $4 \mathrm{~h}$, and

for $1 \mathrm{~h}$, and centrifuged. The supernatant passed through a $\mathrm{C}_{18}$ solid phase extraction column, and then dried

with nitrogen. The hormone extract was obtained by mixing with $1 \mathrm{~mL}$ of the sample diluent (PBS containing

0.1\% Tween-20, gelatin $1 \mu \mathrm{g} / \mathrm{L}$ ) and determined using enzyme-linked immunosorbent assay. The hormone

assay kit was supplied by China Agricultural University, and the content of auxin (IAA), abscisic acid (ABA),

zeatin (ZR), and gibberellin (GA) contents were measured by using the Thermo Multiskan FC enzyme-labeled

instrument.

\section{Statistical analysis}

Statistical analyses were performed using Statistical Product and Service Solutions 19.0 (SPSS Inc.,

Chicago, IL). Quantitative data were expressed as the mean \pm standard error, and multiple comparisons were 
169

170

171

172

173

174

175

176

177

178

179

180

181

182

183

184

185

186

187

188

189

highest difference between the different herbicide treatments and control, to simplify the indicators.

\section{RESULTS}

\section{Effects of fluroxypyr on growth parameters}

After exposing the seedlings to $0.5-4.0 \mathrm{~L}$ ai ha ${ }^{-1}$ fluroxypyr for 5 days, the plant height of Zhangza 5 significantly differed between the control and herbicide treatments. At 10 days post-fluroxypyr treatment, the plant height increased by $10.16 \%, 12.62 \%$, and $5.73 \%$ after exposure to $0.5,1.0$, and $2.0 \mathrm{~L}$ ai ha ${ }^{-1}$, respectively. As shown in Table 1, the leaf area of Zhangza 5 significantly differed between the recommended dose $(1 \mathrm{~L}$ ai $\mathrm{ha}^{-1}$ ) and other treatments after 5 days. A similar response of the leaf area was recorded when Zhangza 5 was exposed to fluroxypyr for 10 days, thereby showing significant difference among treatments compared with the recommended dosage.

\section{Effects of fluroxypyr on stress parameters}

Fluroxypyr treatment at doses ranging from 0 to $4 \mathrm{~L}$ ai ha ${ }^{-1}$ increased $\mathrm{H}_{2} \mathrm{O}_{2}$ and $\mathrm{O}_{2}{ }^{-}$accumulation in plants, with the maximum expression levels obtained after treatment with a dosage of $4 \mathrm{~L}$ ai ha ${ }^{-1}$ for 5 and 10 days. As shown in Table 2, maximum $\mathrm{H}_{2} \mathrm{O}_{2}$ and $\mathrm{O}_{2}{ }^{-}$accumulations significantly increased by treatment with 4

$\mathrm{L}$ ai ha ${ }^{-1}$ fluroxypyr for 5 and 10 days compared with the control. Similarly, treatment with fluroxypyr at the recommended dose (1 L ai ha- ${ }^{-1}$ increased $\mathrm{H}_{2} \mathrm{O}_{2}$ and $\mathrm{O}_{2}{ }^{-}$contents by 1.01- and 1.02- fold relative to the control after 5 days and by 2.02- and 1.05-fold relative to the control after 10 days, respectively. In our studies, we observed a time-dependent decrease in reactive oxygen species (ROS) in response to fluroxypyr exposure.

\section{Effects of fluroxypyr on enzyme activities}

As shown in Figure 1, the SOD, POD, CAT, APX, and GR activities significantly increased. The exposure of Zhangza 5 to increasing levels of fluroxypyr led to increases in SOD, CAT, APX, and GR 
190

191

192

193

194

195

196

197

198

199

200

201

202

203

204

205

206

207

208

209

210

activities. However, further increases in fluroxypyr concentration beyond $2 \mathrm{~L}$ ai ha ${ }^{-1}$ failed to promote SOD,

CAT, APX, and GR accumulation. The activities of SOD, CAT, APX, and GR significantly increased after

treatment with $2 \mathrm{~L}$ ai ha ${ }^{-1}$ fluroxypyr relative to the control. POD activities were stimulated after exposure to

different fluroxypyr concentrations, and its effect was concentration-dependent; the highest POD activity was

observed at $4 \mathrm{~L}$ ai ha ${ }^{-1}$ fluroxypyr. POD activities significantly increased by 2.91 - and 3.53 - fold relative to the control after treatment with $4 \mathrm{~L}$ ai ha ${ }^{-1}$ fluroxypyr for 5 and 10 days, respectively.

\section{Effects of fluroxypyr on net photosynthetic rate and pigments}

As shown in Table $3, P_{N}, E, G_{s}$, and $C h l$ showed a progressive decrease with increasing fluroxypyr concentration. After $1 \mathrm{~L}$ ai ha ${ }^{-1}$ (recommended dose) fluroxypyr treatment for 5 days, $P_{N}$ and $E$ significantly decreased by $23.72 \%$ and $22.56 \%$ compared with the control, respectively. However, $1 \mathrm{~L}$ ai ha ${ }^{-1}$ fluroxypyr treatment for 5 days inhibited $G_{s}$ by $3.53 \%$. Moreover, after with $1 \mathrm{~L}$ ai ha ${ }^{-1}$ fluroxypyr for 10 days, $P_{N}, E$, and $G_{s}$ of the treated plants were reduced by $18.78 \%, 15.12 \%$, and $18.79 \%$ compared with the control, respectively. According to our results, significant differences were recorded between the treatments and control. Chlorophyll content was also significantly affected following fluroxypyr treatment; however, no significant differences were observed between the control and treatment using the recommended dose after 5 and 10 days of exposure.

\section{Effects of fluroxypyr on chlorophyll fluorescence and $\mathbf{P}_{700}$ parameters}

After 5 days of exposure to fluroxypyr, the $\mathrm{F}_{\mathrm{v}} / \mathrm{F}_{\mathrm{m}}$ of treated plants decreased to $0.13 \%, 0.32 \%, 1.71 \%$, and $3.29 \%$ compared with the control, and the differences between treatments were insignificant. Moreover, after 10 days, the $F_{v} / F_{m}$ of the treated plants recovered to control levels. As shown in Figure 2, the changes in Y(II) and ETR(II) were consistent under fluroxypyr treatment, and the values were reduced in a dose-dependent 
211

212

manner. After 5 and 10 days of treatment, $\mathrm{Y}$ (II) decreased from $12.44 \%$ to $22.96 \%$, and from $18.25 \%$ to $32.14 \%$, respectively, and ETR(II) decreased from $12.37 \%$ to $22.69 \%$, and from $14.91 \%$ to $32.31 \%$, respectively. Additionally, Y(NPQ) increased with increasing fluroxypyr doses, and the maximum accumulation was observed at $2 \mathrm{~L}$ ai ha ${ }^{-1}$. During treatment with $2 \mathrm{~L}_{\text {ai ha }} \mathrm{ha}^{-1}$ fluroxypyr, the $\mathrm{Y}(\mathrm{NPQ})$ values were $36.39 \%$, and $50.75 \%$, compared with the control.

PSI activities were substantially affected by fluroxypyr treatment. As shown in Figure 2, Pm, Y(I), and ETR(I) were evidently decreased with increasing fluroxypyr dosage; however, no significant differences between the control and herbicide-treated plants were observed after 5 days of exposure. Treatment with increasing fluroxypyr concentration increased the $\mathrm{Y}(\mathrm{ND})$ of Zhangza 5. The maximum Y(ND) level was observed at fluroxypyr treatment. However, further increasing the dosages of fluroxypyr beyond $2 \mathrm{~L}_{\text {ai }}$ ha ${ }^{-1}$ no longer increased $\mathrm{Y}(\mathrm{ND})$.

\section{Effects of fluroxypyr on endogenous hormones}

Fluroxypyr treatment at doses ranging from 0.5 to $4 \mathrm{~L}$ ai ha ${ }^{-1}$ increased IAA and ABA accumulation in plants, with the maximum accumulation observed at $4 \mathrm{~L}$ ai ha ${ }^{-1}$ (Figure 3). The application of $4 \mathrm{~L}$ ai ha ${ }^{-1}$ fluroxypyr significantly increased IAA and ABA by $26.69 \%$ and $23.36 \%$ relative to that of the control after 5 days of treatment and $5.37 \%$ and $35.53 \%$ relative to that of the control after 10 days of treatment, respectively. A similar response was observed between GA and ZR accumulation in Zhangza 5 exposure to fluroxypyr; GA and ZR decreased with increasing fluroxypyr concentration, and the difference observed between the control and treated plants was significant. After treatment with $1 \mathrm{~L}$ ai ha ${ }^{-1}$ (recommended dose) fluroxypyr for 5 and 10 days, the GA and ZR values significantly decreased by $10.46 \%, 18.72 \%$, and by $13.50 \%, 23.59 \%$ relatively to the control treatment, respectively. 
232

233

234

235

236

237

238

239

240

241

242

243

244

245

246

247

248

249

250

251

252

\title{
Comprehensive evaluation of fluroxypyr on various foxtail millet indices
}

\author{
To further comprehensively evaluate the effects of fluroxypyr on various foxtail millet indices, Fisher
} discriminant analysis was used. Herbicide treatment was used as the grouping variable $\mathrm{Y}$, and the physiological parameters were used as the independent variable $\mathrm{X}$.

(1) Fisher discrimination was used to evaluate the seven indicators of foxtail millet leaf, namely, $\mathrm{H}_{2} \mathrm{O}_{2}\left(\mathrm{X}_{1}\right), \mathrm{O}_{2}^{-}\left(\mathrm{X}_{2}\right), \operatorname{SOD}\left(\mathrm{X}_{3}\right), \operatorname{POD}\left(\mathrm{X}_{4}\right), \mathrm{CAT}\left(\mathrm{X}_{5}\right), \operatorname{APX}\left(\mathrm{X}_{6}\right)$, and $\mathrm{GR}\left(\mathrm{X}_{7}\right)$. The following discriminant functions were obtained:

$$
\begin{aligned}
& Y_{1}=-3.850+4.868 X_{3}+3.588 X_{6}-48.734 X_{7} \\
& Y_{2}=-0.344-1.408 X_{3}+2.886 X_{6}-7.736 X_{7} \\
& Y_{3}=-5.062-0.107 X_{3}+0.020 X_{6}+12.487 X_{7}
\end{aligned}
$$

The cumulative contribution rate of the first-class functions, which is the main function, reached $98.8 \%$.

Thus, $\operatorname{SOD}\left(\mathrm{X}_{3}\right), \operatorname{POD}\left(\mathrm{X}_{4}\right)$, and $\mathrm{GR}\left(\mathrm{X}_{7}\right)$ were used as indices to evaluate the peroxidation characteristics of foxtail millet.

(2) Fisher discrimination was used to evaluate the fourteen indicators of foxtail millet leaf, namely, $P_{N}\left(\mathrm{X}_{1}\right), E\left(\mathrm{X}_{2}\right), G_{s}\left(\mathrm{X}_{3}\right), \quad \operatorname{Chl}\left(\mathrm{X}_{4}\right), \mathrm{F}_{\mathrm{v}} / \mathrm{F}_{\mathrm{m}}\left(\mathrm{X}_{5}\right), \mathrm{Y}(\mathrm{II})\left(\mathrm{X}_{6}\right), \quad \mathrm{ETR}(\mathrm{I})\left(\mathrm{X}_{7}\right), \mathrm{Y}(\mathrm{NPQ})\left(\mathrm{X}_{8}\right), \quad \mathrm{Y}(\mathrm{NO})\left(\mathrm{X}_{9}\right), \mathrm{P}_{\mathrm{m}}\left(\mathrm{X}_{10}\right)$,

$\mathrm{Y}(\mathrm{I})\left(\mathrm{X}_{11}\right), \mathrm{ETR}(\mathrm{I})\left(\mathrm{X}_{12}\right), \mathrm{Y}(\mathrm{ND})\left(\mathrm{X}_{13}\right)$, and $\mathrm{Y}(\mathrm{NA})\left(\mathrm{X}_{14}\right)$. The following discriminant functions were obtained:

$$
\begin{aligned}
& Y_{1}=-252.994+427.640 X_{6}-66.364 X_{8}+143.154 X_{10}+1.396 X_{12} \\
& Y_{2}=-69.158+151.904 X_{6}+96.548 X_{8}+22.743 X_{10}-0.036 X_{12} \\
& Y_{3}=-5.251-91.400 X_{6}-1.385 X_{8}+7.042 X_{10}+0.184 X_{12} \\
& Y_{4}=1.257+2.323 X_{6}-1.378 X_{8}+3.767 X_{10}-0.018 X_{12}
\end{aligned}
$$

The cumulative contribution rate of the first-class functions, which is the main function, reached $94.4 \%$. 
253 Thus, $\mathrm{Y}(\mathrm{II})\left(\mathrm{X}_{6}\right), \mathrm{Y}(\mathrm{NPQ})\left(\mathrm{X}_{8}\right), \mathrm{P}_{\mathrm{m}}\left(\mathrm{X}_{10}\right)$, and $\mathrm{ETR}(\mathrm{I})\left(\mathrm{X}_{12}\right)$ were used as indices to evaluate the photosynthetic

254 characteristics of foxtail millet.

255

(3) Fisher discrimination was used to evaluate the four indicators of foxtail millet leaf, namely, $\mathrm{IAA}\left(\mathrm{X}_{1}\right)$,

256

257

258

259

260

261

262

263

264

265

266

267

268

269

270

271

272

273

$\mathrm{GA}\left(\mathrm{X}_{2}\right), \mathrm{ZR}\left(\mathrm{X}_{3}\right)$, and $\mathrm{ABA}\left(\mathrm{X}_{4}\right)$. The following discriminant functions were obtained:

$$
\begin{aligned}
& Y_{1}=-78.315+8.217 X_{2}+0.229 X_{4} \\
& Y_{2}=-13.841+1.139 X_{2}+0.073 X_{4}
\end{aligned}
$$

The cumulative contribution rate of the first-class functions, which is the main function, reached $94.4 \%$.

Thus, $\mathrm{GA}\left(\mathrm{X}_{2}\right)$ and $\mathrm{ABA}\left(\mathrm{X}_{4}\right)$ were used as indices to evaluate the endogenous hormone characteristics of foxtail millet.

As shown in Table 4, the cumulative contribution rate of the first two principal components reached 93.72\%. Thus, the first two principal components were further analyzed. The first principal component accounted for $59.23 \%$ of the variance observed, whereas the second principal component accounted for $34.49 \%$ of this variance. The load values of ERT (I), Y (II), and GA, which were 0.978, 0.975 and 0.963 , respectively, were the largest in the first principal component. ABA also showed high absolute loading value in the first principal component, but exhibited a negative effect. Therefore, the first principal component could explain the photosynthetic characteristics and endogenous hormones of foxtail millet. In the second principal component, the loading values of plant height and leaf area were relatively high and could represent the growth parameters of foxtail millet.

According to the principal component analysis, the model was set up as follows: $\mathrm{F}=0.592 \mathrm{Z}_{1}+0.345 \mathrm{Z}_{2}$.

The comprehensive evaluation scores of the 2 and $4 \mathrm{~L}$ ai ha ${ }^{-1}$ fluroxypyr treatments were relatively low, which indicated that high fluroxypyr concentrations negatively affected the photosynthetic characteristics and 
274

275

276

277

278

279

280

281

282

283

284

285

286

287

288

289

290

291

292

293

294

endogenous hormones of foxtail millet. Furthermore, the comprehensive evaluation scores of the 0.5 and $1 \mathrm{~L}$ ai $\mathrm{ha}^{-1}$ fluroxypyr treatments were 0.941 and 2.007 , respectively, and the scores of first two principal components were positive, which indicated that the moderate concentrations of fluroxypyr positively affected the peroxidation characteristics, photosynthetic characteristics, and endogenous hormones of foxtail millet (Table 5). Consequently, the scores of the two factors in $1 \mathrm{~L}$ ai ha ${ }^{-1}$ fluroxypyr treatments were both relatively high and represented the comprehensive effect of herbicide in foxtail millet (Figure 4).

\section{DISCUSSION}

Numerous studies have demonstrated that excessive application of fluroxypyr in the environment inhibits plant growth (Guo et al., 2010; Guo et al., 2018). In the present study, we found that fluroxypyr had a slight effect on plant growth at relatively low doses, but exerted significant influence at high doses. The growth inhibition of fluroxypyr is closely related to the accumulation of $\mathrm{O}_{2}^{-}$and $\mathrm{H}_{2} \mathrm{O}_{2}$ in plants (Guo et al., 2010). According to the inhibitory effect of fluroxypyr on ROS, the present study showed that the maximum accumulation of $\mathrm{H}_{2} \mathrm{O}_{2}$ and $\mathrm{O}_{2}^{-}$occurs when plants are treated with $4 \mathrm{~L}$ ai ha ${ }^{-1}$ fluroxypyr for 5 and 10 days.

Herbicide-induced oxidative stress causes cellular peroxidation and molecular damage through ROS overaccumulation (Kehrer, 1993; Chen et al., 2009). To inhibit ROS action, plants have evolved protective enzymatic mechanisms, such as those involving SOD, POD and CAT (Khan \& Kour, 2007). In most cases, the enzyme-based antioxidant system is one of the important ways for plants to resist environmental stress, which reflects not only the level of toxicity but also the ability to tolerate stress. Our analyses showed that the SOD, POD, CAT, APX, and GR activities generally increased at low fluroxypyr dosages but decreased at high fluroxypyr dosages, thereby reflecting an increased degree of oxidative stress.

Several symptoms related to changes in plant photosynthesis were observed in this work. After fluroxypyr

Peer] reviewing PDF | (2019:02:34816:3:0:NEW 23 Aug 2019) 
295

296

297

298

299

300

301

302

303

304

305

306

307

308

309

310

311

312

313

314

315 treatment, one such visible symptom was chlorosis, which showed that chlorophyll was certainly sensitive to fluroxypyr exposure. In the present study, chlorophyll formation was considerably suppressed at high concentrations ( 2 and $4 \mathrm{~L}$ ai ha ${ }^{-1}$ ). A reduction in $P_{N}$, as reflected by the decrease in $E$ and $G_{S}$, was also noted after fluroxypyr treatment. These results suggested that fluroxypyr destroyed the chloroplast structure of foxtail millet, increases the risk of photo-oxidation damage, and reduced light absorption, transmission, and distribution between PSII and PSI (Havaux, Strasser \& Creppin, 1991).

Chlorophyll and gas exchange measurements are nondestructive methods used to identify the modes of action of certain herbicides in the ecological risk assessment of herbicide exposure. In this study, chlorophyll fluorescence showed that fluroxypyr treatment affected photosynthesis efficiency, even in the absence of phenotypic symptoms (Qian et al., 2014). Our analyses showed that each fluroxypyr treatment caused different degrees of $\mathrm{F}_{\mathrm{v}} / \mathrm{F}_{\mathrm{m}}$ decrease, and the differences among treatments after 5 days of exposure were insignificant. Compared with the control, only the maximum fluroxypyr dose (4-fold the recommended dose) showed significantly reduced $\mathrm{F}_{\mathrm{v}} / \mathrm{F}_{\mathrm{m}}$ values. Given that fluroxypyr inhibited electron transport in Zhangza 5, it also caused the decline in Y(II) and ETR (II). Y(NPQ) represents the regulated photo-protective NPQ mechanism, namely, dissipating the fraction of energy in the form of heat (Christof \& Ulrich, 2008). Y(NPQ) also dissipates excess PSII energy via the xanthophyll cycle and associated carotenoids (Deng et al., 2013). In the present study, fluroxypyr treatment caused the increase in $\mathrm{Y}(\mathrm{NO})$, which demonstrated that the plant cannot protect itself against damage from excess illumination due to blocking the regulatory mechanism of the nonphotochemical dissipation of energy. Consistent with our results, Guo et al. (2018) reported that sethoxydim has similar effects on the photosynthetic pigments, photosynthetic gas exchange and chlorophyll fluorescence parameters of foxtail millet.

PeerJ reviewing PDF | (2019:02:34816:3:0:NEW 23 Aug 2019) 

study, Pm, Y(I), and ETR(II) decreased with increasing fluroxypyr doses, and were significantly inhibited compared with those of the control. Fluroxypyr inhibited electron transport in Zhangza 5, which caused an increase in $\mathrm{Y}(\mathrm{NA}) . \mathrm{Y}(\mathrm{NA})$ is an important photo-damage indicator in PSI, and it is affected by dark adaptation and level of damage to $\mathrm{CO}_{2}$ fixation. $\mathrm{Y}(\mathrm{NA})$ was significantly increased by treatment with $>2 \mathrm{~L}$ ai ha ${ }^{-1}$ fluroxypyr dose, showing that fluroxypyr aggravated the injury of PSII in foxtail millet leaves, reduced electronic accumulation of acceptor-side in PSI, blocked the dark reaction process, and decreased the fixed proton gradient and degree of damage of PSII (Yuan et al., 2013). In our study, Y(ND) in Zhangza 5 increased at the fluroxypyr concentrations of $\leq 1 \mathrm{~L}$ ai ha ${ }^{-1}$. 
337

photosynthesis. ABA reduced the electric potential of the chloroplast cell membrane, thereby reducing photosynthetic electron transport, whereas ZR could increase the Rubisco activity and promote photosynthetic electron transport.

High efficiency and safety are the main objectives of herbicide application. Eleven simplified indicators were screened by Fisher discriminant analysis, and principal component analysis was used to comprehensively evaluate the growth parameters, peroxidation characteristics, photosynthetic characteristics and endogenous hormones of foxtail millet at different fluroxypyr dosages. The model was set up as follows: $F=0.592 Z_{1}+$ $0.345 Z_{2}$. The cumulative contribution rate of the first two principal components reached $93.72 \%$. The first principal component explained $59.23 \%$ of the variance including photosynthetic characteristics and endogenous hormones of foxtail millet. The second principal component accounted for $34.49 \%$ of the variance and had high loadings for growth parameters. Consequently, these two principal components were selected to represent the comprehensive effect of fluroxypyr on foxtail millet.

\section{CONCLUSIONS}

The effect of fluroxypyr on foxtail millet is complex and involves combination of several factors. The application of $1 \mathrm{~L}$ ai ha-1 fluroxypyr exerted minimal effects on growth parameters, oxidase activity, photosynthetic activity, and endogenous hormones, indicating its efficient and safe benefits in foxtail millet application.

\section{ACKNOWLEDGMENTS}

We are gratefully acknowledgment help from Professor Yuguo Wang, Shanxi Agricultural University, for suggestion on the manuscript. Thanks are also due to three anonymous reviewers and editor for their thoughtful and valuable comments and suggestions, which helped in improving the manuscript. 


\section{REFERENCE}

359 [1]Rubin B. 1996. Herbicide-resistant weeds - the inevitable phenomenon: mechanisms, distribution and

360

361

362

363

364

365

366

367

368

369

370

371

372

373

374

375

376

377

378 significance. Z. Pflkrankh. Pflschutz XV 17-32

[2]Chen J, Shiyab S, Han FX, Monts DL, Waggoner CA, Yang ZM, Su Y. 2009. Bioaccumulation and physiological effects of mercuryin Pteris vittata and Nephrolepis exaltata. Ecotoxicology 18:110-121

[3]Christof K, Ulrich S. 2008. Complementary PS II quantum yields calculated from simple fluorescence parameters measured by PAM fluorometry and the saturation pulse method. PAM Apply Notes 1:27-35

[4]Deng CN, Zhang DY, Pan XL, Chang FQ, Wang SZ. 2013. Toxic effects of mercury on PSI and PSII activities, membrane potential and transthylakoid proton gradient in Microsorium pteropus. Journal of Photochemistry and Photobiology B:Biology 127:1-7

[5]Dong BD, Liu MY, Jiang JW, Shi CH, Wang XM, Qiao YZ, Liu YY, Zhao ZH, Li DX, Si FY. 2014. Growth, grain yield, and water use efficiency of rain-fed spring hybridmillet (Setaria italica) in plasticmulched and unmulched fields. Agricultural Water Management 143:93-101

[6]Elstner EF, Heupel A. 1976. Inhibition of nitrite formation from hydroxylammonium chloride: A simple assay for superoxide dismutase. Analytical Biochemistry 70:616-620

[7]Grossmann K. 2010. Auxin herbicide: current status of mechanism and mode of action. Pest Management Science 66:113-120

[8]Guo MJ, Wang YG, Dong SQ, Wen YY, Song XE, Guo PY. 2018. Photochemical changes and oxidative damage in four foxtail millet varieties following exposure to sethoxydim. Photosynthetica 56:820-831

[9]Guo LW, Jing C, Ling T, Hong Y. 2010. Fluroxypyr triggers oxidative damage by producing superoxide and hydrogen peroxide in rice (Oryza sativa). Ecotoxicology 19:124-132 
$379[10]$ Thiel H, Varrelmann M. 2014. Identification of a new PSII target site $p s b$ A muta-tion leading to D1 amino

380

381

382

383

384

385

386

387

388

389

390

391

392

393

394

395

396

397

398

399

acid Leu218 Val exchange in the Chenopodiumalbum D1 protein and comparison to cross-resistance profiles

of known modifications at positions 251 and 264. Pest Management Science 70:278-285

[11]Hellou J, Leonard J, Cook A, Doe K, Dunphy K, Jackman P, Tremblay L, Flemming JM. 2009.

Comparison of the partitioning of pesticides relative to the survival and behaviour of exposed amphipods.

Ecotoxicology 18:27-33

[12]Havaux M, Strasser RJ, Greppin H. 1991. A theoretical and experimental analysis of the qP and qN coefficients of chlorophyll fluorescence quenching and their relation to photochemical and nonphotochemical events. Photosynthesis Research 27:41-55

[13]Halliwell B, Foyer CH. 1978. Properties and physiological function of a glutathione reductase purified from spinachleaves by affinity chromatography. Planta 139: 9-17

[14]Kehrer PP. 1993. Free radicals as mediators of tissue injury and disease. Critical Reviews in Toxicology $23: 21-48$

[15]Khan SM, Kour G. 2007. Subacute oral toxicity of chlorpyriphos and protective effect of green tea extract.

Pest Biochemistry and Physiology 89:118-123

[16]Klughammer C, Schreiber U. 2008. Saturation Pulse method for assessment of energy conversion in PS I. PAM Apply Notes 1:11-14

[17]Lichtenthaler HK. 1987. Chlorophylls and carotenoids: pigments of photosynthetic biomembranes.

Methods in Enzymology 148:350-382

[18] Liu LC. 2014. Study 20\% fluroxypyr control broadleaf weeds in maize field. Modernizing Agriculture 417:4-5(in chinese) 
400 [19]Vila-Aiub MM, Goh SS, Gaines TA, Han HP, Busi R, Yu Q, Powles SB. 2014. No fitnesscost of 401 glyphosate resistance endowed by massive EPSPS gene amplification in Amaranthus palmeri. Planta $402 \quad 239: 793-801$

403 [20]Matzrafi M, Gadri Y, Frenkel E, Rubin B, Peleg Z. 2014. Evolution of herbicide resistance mechanisms in 404 grass weeds. Plant Science 229:43-52

405 [21]Nakano Y, Asada K. 1981. Hydrogen peroxide is scavenged by ascrobate specific peroxidase in spinach 406 chloroplasts. Plant and Cell Physiology 22:867-880

407 [22]Tranel PJ, Wright TR, Heap I. 2014. ALS Mutations from Herbicide-resistant Weeds. http://www.weedscience.com

[23]Pfündel E, Klughammer C, Schreiber U. 2008. Monitoring the effects of reduced PS II antenna size on quantum yields of photosystems I and II using the Dual-PAM-100 measuring system. PAM Apply Notes 1:21-

[24]Qian HF, Tsuji T, Endo T, Sato F. 2014. The PGR5 and NDH pathways in photosynthetic cyclic electron transfer respond differently to sub-lethal treatment with photosystem-interfering herbicides. Journal of

[25]Sammons RD, Gaines TA. 2014. Glyphosate resistance: state of knowledge. Pest Management Science

70:1367-1377

[26]Scheller HV, Haldrup A. 2005. Photoinhibition of photosystem I. Planta 221:5-8

[27]Kaundun SS. 2014. Resistance to acetyl-CoA carboxylase-inhibiting herbicides. Pest Management Science

70:1405-1417

420

[28]Gaines TA, Zhang W, Wang D, Bukun B, Chisholm ST, Shaner DL, Nissen SJ, Patzoldt WL, Tranel PJ, 
421 Culpepper AS, Grey TL, Webster TM, Vencill WK, Sammons RD, Jiang J, Preston C, Leach JE, Westra P.

422 2010. Gene amplification confers glyphosate resistance in Amaranthus palmeri. Proceeding of the National

423 Academy of Science of the USA 107:1029-1034

424 [29]Tian BH, Wang JG. 2010. Study on selection of suitable herbicides for hybrid millet. Journal of Hebei

Agricultural Sciences 14:46-47 (in Chinese)

[30]Wang YY, Zhou R, Zhou X. 1994. Endogenous levels of ABA and cytokinins and their relation to

stomatal behavior in dayflower (Commelina communis L.). Journal of Plant Physiology 144:45-48

[31]Yuan XY, Guo PY, Qi X. Ning N, Wang H, Wang HF, Wang X, Yang YJ. 2013. Safety of herbicide

Sigma Broad on Radix Isatidis (Isatis indigotica Fort.) seedlings and their photosynthetic physiological

responses. Pesticide Biochemistry and Physiology 106:45-50

[32]Zhang GY, Liu X, Quan ZW, Cheng SF, Xu X, Pan SK, Xie M, Zeng P, Yue Z, Wang WL, Tao Y, Bian C,

Han CL, Xia QJ, Peng XH, Cao R, Yang XH, Zhan DL, Hu JC, Zhang YX, Li HN, Li H, Li N, Wang JY,

Wang CC, Wang RY, Guo T, Cai YJ, Liu CZ, Xiang HT, Shi QX, Huang P, Chen QC, Li YR, Wang J, Zhao

ZH, Wang J. 2012. Genome sequence of foxtail millet (Setaria italica) provides insights into grass evolution

and biofuel potential. Nature Biotechnology 30:549-556

[33]Zhou HZ, Liu HX, Bo KY, Jia HY, Lv P. 2012. Study on prediction model of millet yield loss caused by

weeds in summer season millet field. Journal of Agricultural 2:12-15 (in Chinese)

[34]Zhou YF, Wang DQ, Liu ZB, Wang N, Wang YT, Li FX, Xu WJ, Huang RD. 2014. Effects of Drought 
Figure 1

Figure 1. Effect of fluroxypyr on superoxide, peroxidase, catalase, ascorbate peroxidase, and glutathione reductase activities of foxtail millet.

SOD, POD, CAT, APX and GR represent superoxide, peroxidase, catalase, ascorbate peroxidase, and glutathione reductase activities, respectively.
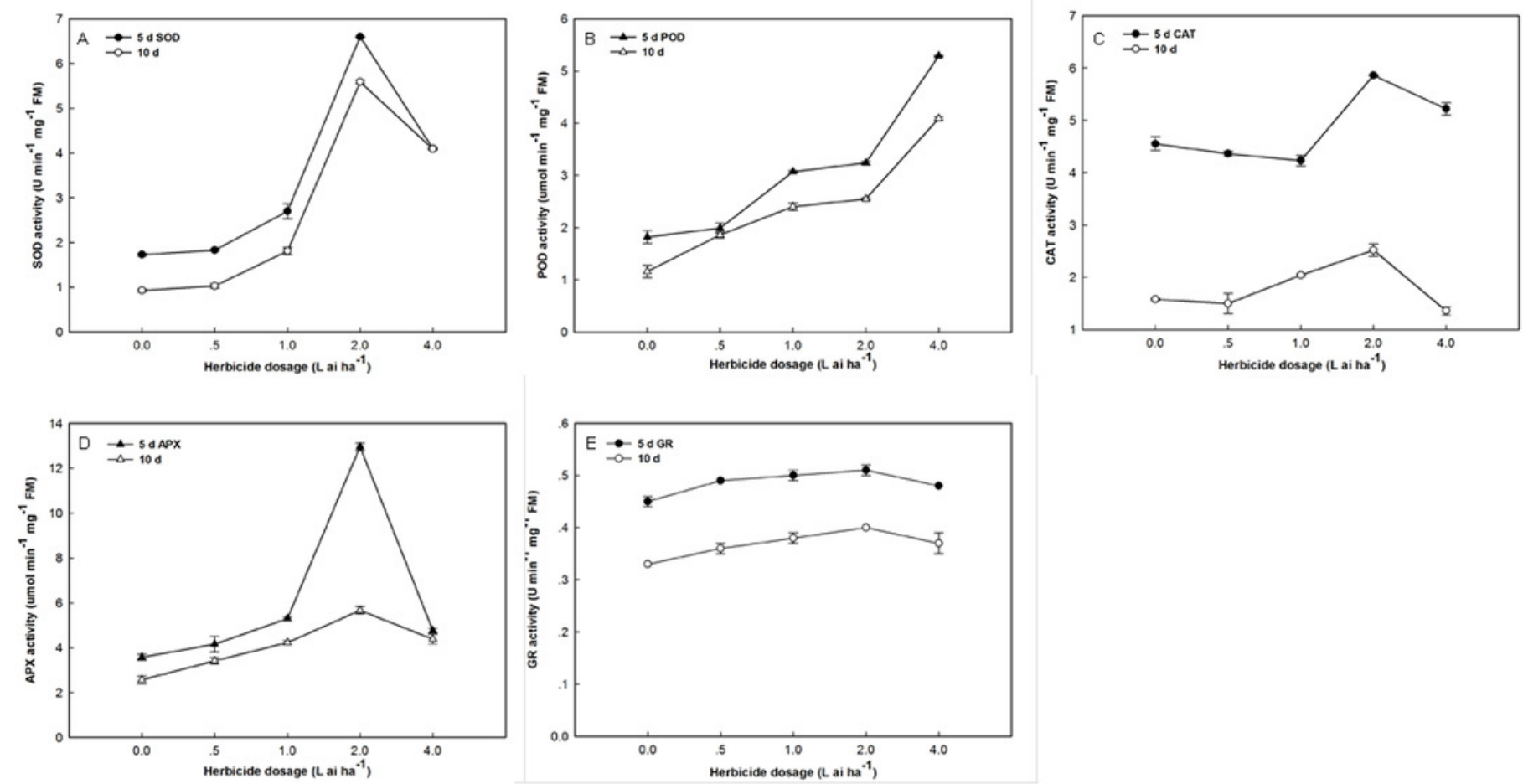


\section{Figure 2}

Figure 2. Effect of fluroxypyr on chlorophyll fluorescence and $P_{700}$ parameters of foxtail millet.

$F_{v} / F_{m}$ - maximum quantum yield of PS; Y(II)- PSII effective quantum yield; ETR(II)- PSII electron transport rate. Y(NO)- quantum yield of nonregulated energy dissipation in PSII; $\mathrm{Y}(\mathrm{NPQ})$ - quantum yield of regulated energy dissipation in PSII. Pm - maximal $\mathrm{P}_{700}$ change; Y(I)- photochemical quantum yield of PSI; ETR(I)- PSI electron transport rate; Y(NA)- quantum yield of nonphotochemical energy dissipation due to acceptor-side limitation in PSI; Y(ND)quantum yield of nonphotochemical energy dissipation due to donor-side limitation in PSI.
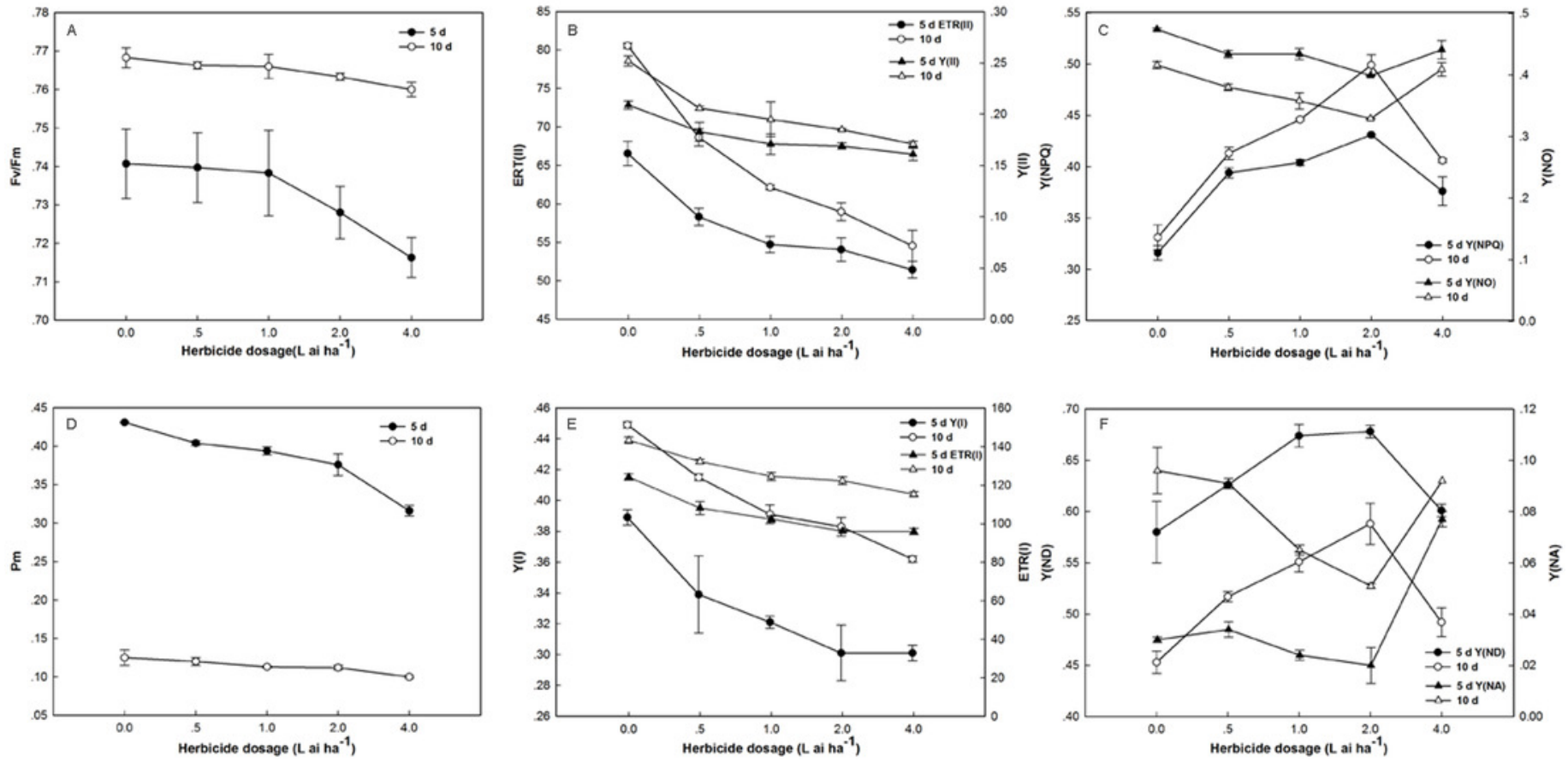
Figure 3

Figure 3. Effect of fluroxypyr on endogenous hormones of foxtail millet.

IAA, GA, ABA and ZR represent auxin, gibberellin, zeatin, abscisic acid, respectively.

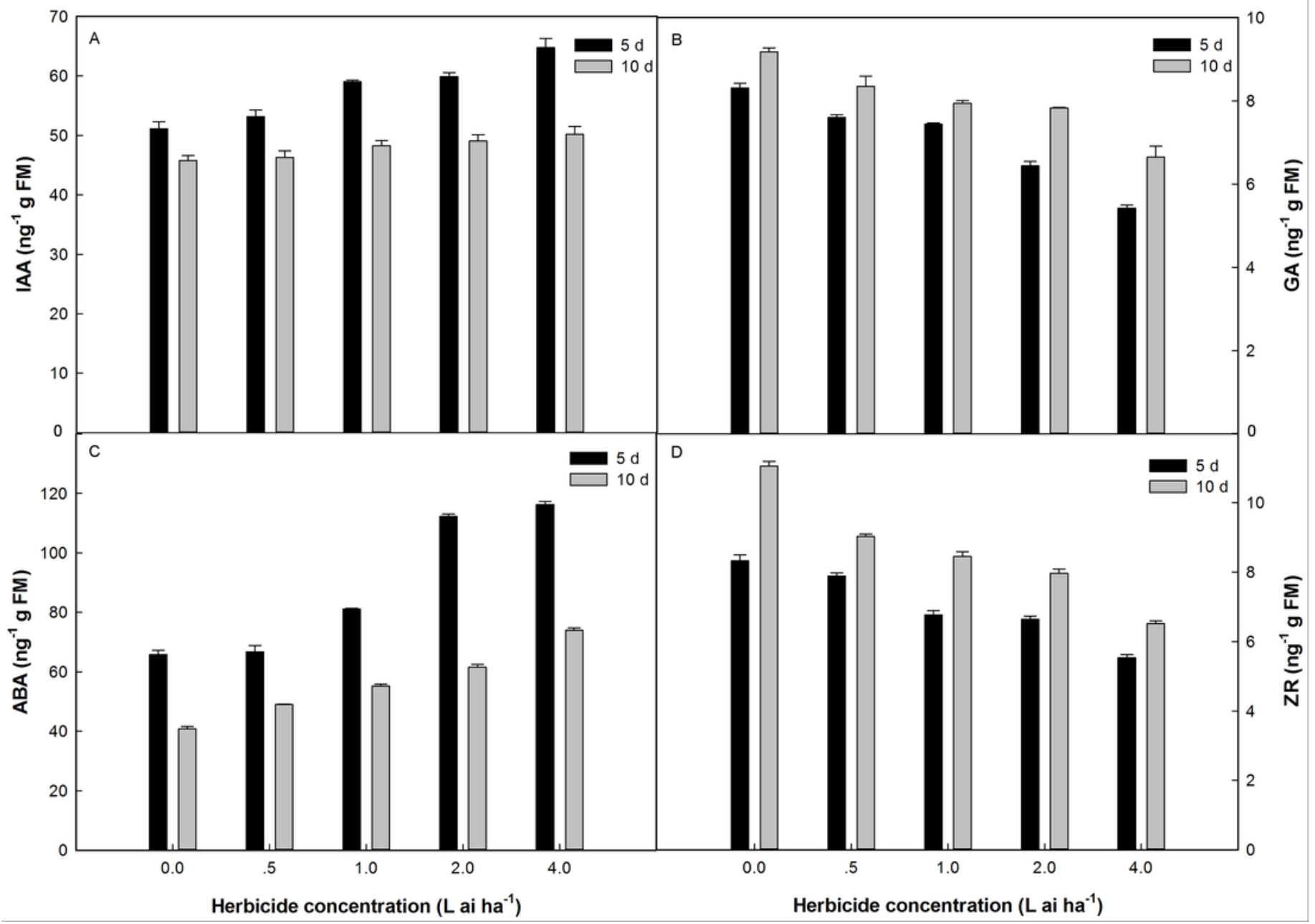


Figure 4

Figure 4. PCA score plot, the percentages of $\mathrm{PC} 1$ and $\mathrm{PC2}$ representing the total variances of samples.

((1)-(3)) represent fluroxypyr dosage $4.0 \mathrm{~L}$ ai ha- ${ }^{-1},((4)-(6)$ represent fluroxypyr dosage $2.0 \mathrm{~L}$ ai ha ${ }^{-1},((7)-(9))$ represent $0.5 \mathrm{~L}_{\text {ai }} \mathrm{ha}^{-1},((10)-(12))$ represent fluroxypyr dosage $1.0 \mathrm{~L}$ ai ha ${ }^{-4}$, and ((13)-(14)) represent fluroxypyr dosage $0 \mathrm{~L}$ ai ha ${ }^{-1}$, respectively.

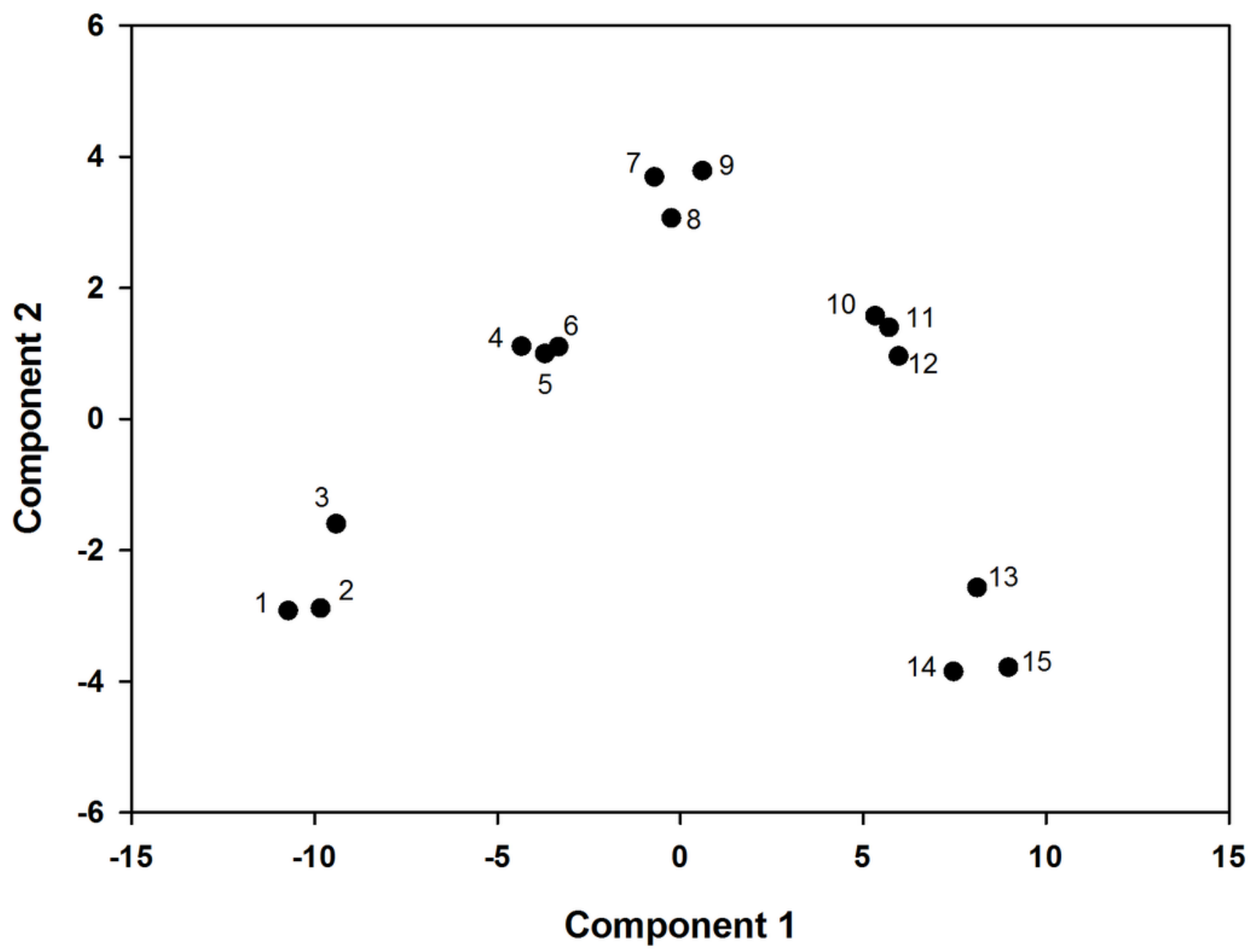




\section{Table $\mathbf{1}$ (on next page)}

Table 1 Effect of fluroxypyr application on growth parameters in foxtail millet

Different letters in the same column indicate a significantly difference at the $P<0.05$ level by Duncan's new multiple range test. 


\begin{tabular}{cccccc}
\hline \multirow{2}{*}{$\left.\begin{array}{c}\text { Herbicide dosage } \\
(\mathrm{L} \text { ai ha-1 }\end{array}\right)$} & \multicolumn{2}{c}{ Plant height $(\mathrm{cm})$} & & \multicolumn{2}{c}{ Leaf area $\left(\mathrm{cm}^{2}\right)$} \\
\cline { 2 - 3 } \cline { 5 - 6 } & 5 Day & 10 Day & & 5 Day & 10 Day \\
\hline 0 & $26.05 \pm 0.23 \mathrm{c}$ & $30.50 \pm 0.34 \mathrm{~cd}$ & & $8.00 \pm 0.48 \mathrm{~b}$ & $12.10 \pm 0.15 \mathrm{~b}$ \\
0.5 & $29.95 \pm 0.46 \mathrm{~b}$ & $33.60 \pm 0.57 \mathrm{ab}$ & & $9.71 \pm 0.07 \mathrm{~b}$ & $12.50 \pm 0.18 \mathrm{~b}$ \\
1 & $32.50 \pm 0.02 \mathrm{a}$ & $34.35 \pm 0.23 \mathrm{a}$ & & $13.94 \pm 0.43 \mathrm{a}$ & $15.49 \pm 0.32 \mathrm{a}$ \\
2 & $28.60 \pm 1.41 \mathrm{~b}$ & $32.25 \pm 0.95 \mathrm{bc}$ & & $8.70 \pm 0.69 \mathrm{~b}$ & $12.18 \pm 0.36 \mathrm{~b}$ \\
4 & $23.60 \pm 1.21 \mathrm{~d}$ & $30.10 \pm 0.02 \mathrm{~d}$ & & $7.78 \pm 1.77 \mathrm{~b}$ & $10.75 \pm 0.33 \mathrm{c}$ \\
\hline
\end{tabular}

2 Different letters in the same column indicate a significantly difference at the $P<0.05$ level by Duncan's new 3 multiple range test.

4 


\section{Table 2 (on next page)}

Table 2 Effect of fluroxypyr application on stress parameters in foxtail millet

Different letters in the same column indicate a significantly difference at the $P<0.05$ level by Duncan's new multiple range test.

FM, fresh mass. 
Table 2 Effect of fluroxypyr application on stress parameters in foxtail millet

\begin{tabular}{|c|c|c|c|c|}
\hline \multirow{2}{*}{$\begin{array}{l}\text { Herbicide dosage } \\
\qquad(\mathrm{L} \text { ai ha-1) }\end{array}$} & \multicolumn{2}{|c|}{$\mathrm{H}_{2} \mathrm{O}_{2}$ content (umol g-1 FM) } & \multicolumn{2}{|c|}{$\mathrm{O}_{2}^{-}$generating rate $\left(\mathrm{nmol} \mathrm{g}^{-1} \mathrm{~min}^{-1} \mathrm{FM}\right)$} \\
\hline & 5 Day & 10 Day & 5 Day & 10 Day \\
\hline 0 & $40.70 \pm 0.02 \mathrm{c}$ & $15.53 \pm 0.05 \mathrm{e}$ & $164.18 \pm 1.09 \mathrm{~d}$ & $153.06 \pm 0.41 \mathrm{c}$ \\
\hline 0.5 & $40.83 \pm 0.02 \mathrm{c}$ & $23.69 \pm 0.03 \mathrm{~d}$ & $167.26 \pm 0.34 c$ & $159.45 \pm 0.95 b$ \\
\hline 1 & $41.16 \pm 0.03 c$ & $31.40 \pm 0.05 \mathrm{c}$ & $168.20 \pm 0.54 c$ & $160.87 \pm 0.95 b$ \\
\hline 2 & $42.96 \pm 0.01 b$ & $36.40 \pm 0.06 b$ & $177.19 \pm 0.85 b$ & $162.05 \pm 0.54 b$ \\
\hline 4 & $51.30 \pm 0.03 \mathrm{a}$ & $39.06 \pm 0.07 \mathrm{a}$ & $193.28 \pm 0.41 \mathrm{a}$ & $166.07 \pm 1.63 \mathrm{a}$ \\
\hline
\end{tabular}

2 Different letters in the same column indicate a significantly difference at the $P<0.05$ level by Duncan's new

3 multiple range test.

4 FM, fresh mass. 


\section{Table 3 (on next page)}

Table 3 Effect of fluroxypyr application on photosynthetic parameter and pigments in leaves of foxtail millet

Different letters in the same column indicate a significantly difference at the $P<0.05$ level by

Duncan's new multiple range test. $P_{N}, E, G_{s}$ and $C h l$ represent photosynthetic rate,

Transpiration rate, stomatal conductance, chorophyll content, respectively. 
1

Table 3 Effect of fluroxypyr application on photosynthetic parameter and pigments in leaves of foxtail millet

\begin{tabular}{|c|c|c|c|c|c|c|c|c|}
\hline \multirow{2}{*}{$\begin{array}{c}\text { Herbicide } \\
\text { dosage } \\
\left(\mathrm{L} \text { ai ha }{ }^{-1}\right)\end{array}$} & \multicolumn{2}{|c|}{$P_{N}\left[\mathrm{umol}\left(\mathrm{CO}_{2}\right) \mathrm{m}^{-2} \mathrm{~s}^{-1}\right]$} & \multicolumn{2}{|c|}{$E\left[\mathrm{umol}\left(\mathrm{H}_{2} \mathrm{O}_{2}\right) \mathrm{m}^{-2} \mathrm{~s}^{-1}\right]$} & \multicolumn{2}{|c|}{$G_{s}\left[\operatorname{umol}\left(\mathrm{CO}_{2}\right) \mathrm{m}^{-2}\right]$} & \multicolumn{2}{|c|}{$\operatorname{Chl}\left(\mathrm{mg} \mathrm{g}^{-1}\right)$} \\
\hline & 5 Day & 10 Day & 5 Day & 10 Day & 5 Day & 10 Day & 5 Day & 10 Day \\
\hline 0 & $16.86 \pm 0.31 \mathrm{a}$ & $26.56 \pm 0.14 \mathrm{a}$ & $2.57 \pm 0.01 \mathrm{a}$ & $4.76 \pm 0.09 \mathrm{a}$ & $67.53 \pm 0.18 \mathrm{a}$ & $\begin{array}{c}120.99 \pm 2.76 \\
\mathrm{a}\end{array}$ & $9.57 \pm 1.13 \mathrm{a}$ & $\begin{array}{c}14.24 \pm 0.75 \\
\mathrm{a}\end{array}$ \\
\hline 0.5 & $14.81 \pm 0.52 b$ & $\begin{array}{c}23.81 \pm 0.73 \\
b\end{array}$ & $\begin{array}{c}2.17 \pm 0.06 \mathrm{a} \\
\mathrm{b}\end{array}$ & $\begin{array}{c}4.31 \pm 0.02 \\
\mathrm{~b}\end{array}$ & $61.81 \pm 2.09 \mathrm{~b}$ & $\begin{array}{c}108.81 \pm 0.95 \\
\mathrm{~b}\end{array}$ & $9.26 \pm 0.03 \mathrm{a}$ & $\begin{array}{c}13.82 \pm 0.24 \\
\mathrm{a}\end{array}$ \\
\hline 1 & $12.86 \pm 0.48 \mathrm{c}$ & $\begin{array}{c}21.57 \pm 0.91 \\
b\end{array}$ & $1.99 \pm 0.32 \mathrm{~b}$ & $4.04 \pm 0.01 \mathrm{c}$ & $\begin{array}{c}65.14 \pm 0.79 a \\
b\end{array}$ & $98.25 \pm 2.63 \mathrm{c}$ & $\begin{array}{c}8.33 \pm 0.50 \mathrm{a} \\
\mathrm{b}\end{array}$ & $\begin{array}{c}13.55 \pm 0.09 \\
\mathrm{a}\end{array}$ \\
\hline 2 & $\begin{array}{c}11.88 \pm 0.47 \mathrm{c} \\
\mathrm{d}\end{array}$ & $\begin{array}{c}22.27 \pm 1.13 \\
b\end{array}$ & $\begin{array}{c}1.72 \pm 0.09 \mathrm{~b} \\
\mathrm{c}\end{array}$ & $3.85 \pm 0.10 \mathrm{c}$ & $51.67 \pm 1.93 \mathrm{c}$ & $91.68 \pm 4.74 \mathrm{c}$ & $\begin{array}{c}7.17 \pm 0.07 b \\
\mathrm{c}\end{array}$ & $\begin{array}{c}11.75 \pm 0.24 \\
\mathrm{~b}\end{array}$ \\
\hline 4 & $11.28 \pm 0.47 \mathrm{~d}$ & $16.95 \pm 0.36 \mathrm{c}$ & $1.24 \pm 0.04 \mathrm{c}$ & $\begin{array}{c}3.16 \pm 0.03 \\
\mathrm{~d}\end{array}$ & $50.03 \pm 1.63 \mathrm{c}$ & $74.71 \pm 2.55 \mathrm{~d}$ & $5.83 \pm 0.21 \mathrm{c}$ & $\begin{array}{c}10.92 \pm 0.42 \\
\mathrm{~b}\end{array}$ \\
\hline
\end{tabular}

Different letters in the same column indicate a significantly difference at the $P<0.05$ level by Duncan's new multiple range test.

$P_{N}, E, G_{s}$ and $C h l$ represent photosynthetic rate, Transpiration rate, stomatal conductance, chorophyll content, respectively. 
Table 4 (on next page)

Table 4 Component matrix and variance explained by principal component 
Table 4 Component matrix and variance explained by principal component

\begin{tabular}{|c|c|c|}
\hline \multirow[b]{2}{*}{ Traits } & \multicolumn{2}{|c|}{ Component weight } \\
\hline & Component 1 & Component 2 \\
\hline Plant height & 0.189 & 0.975 \\
\hline Leaf area & 0.146 & 0.888 \\
\hline SOD activity & 0.175 & 0.965 \\
\hline POD activity & -0.926 & -0.245 \\
\hline GR activity & -0.702 & 0.640 \\
\hline $\mathrm{Y}(\mathrm{II})$ & 0.963 & -0.233 \\
\hline Y(NPQ) & -0.652 & 0.653 \\
\hline $\mathrm{P}_{\mathrm{m}}$ & 0.944 & 0.255 \\
\hline $\operatorname{ETR}(\mathrm{I})$ & 0.978 & -0.206 \\
\hline GA & 0.975 & 0.184 \\
\hline $\mathrm{ABA}$ & -0.963 & -0.178 \\
\hline Eigenvalue & 6.515 & 3.794 \\
\hline Cumulative contribution (\%) & 59.230 & 93.722 \\
\hline
\end{tabular}

2 


\section{Table 5 (on next page)}

Table 5 Principal score and general score of comprehensive evaluation 
1

Table 5 Principal score and general score of comprehensive evaluation

\begin{tabular}{cccc}
\hline Treatment & Prin1 score & Prin2 score & Composite score F \\
\hline 0.5 & 0.083 & 2.585 & 0.941 \\
1 & 2.998 & 0.672 & 2.007 \\
2 & -4.242 & 0.638 & -2.291 \\
4 & -7.850 & -2.110 & -5.375 \\
\hline
\end{tabular}

2 